\title{
THE BENEFIT EFFECT OF GINGER SUPPLEMENTATION AGAINST NICKEL-INDUCED HEPATOTOXICITY IN ALBINO WISTAR RATS
}

\author{
SARA DERBAL ${ }^{1}$, ZINE KECHRID ${ }^{2 *}$ \\ ${ }^{1}$ Department of Biology, Laboratory of Animal Ecophysiology, Faculty of Sciences, Badji Mokhtar University, Annaba, Algeria. ${ }^{2}$ Department \\ of Biochemistry, Laboratory of Applied Biochemistry and Microbiology, Faculty of Sciences, Badji Mokhtar University, Annaba, Algeria. \\ Email: kechridzine@yahoo.fr \\ Received: 30 May 2019, Revised and Accepted: 17 July 2019
}

ABSTRACT

Objective: This study was performed to study the potential capacity effect of ginger on the modulation effects of nickel-induced hepatotoxicity.

Methods: Thirty-two female albino Wistar rats were divided into four groups of eight each. One served as a control group, the second group (Gi) received ginger $20 \mathrm{~g} / \mathrm{kg}$ diet, while the third group (Ni) was given nickel $800 \mathrm{mg} / \mathrm{L}$ in their drinking water as $\mathrm{NiSO}_{4} 6 \mathrm{H}_{2} \mathrm{O}$ and the fourth group ( $\mathrm{Ni}+\mathrm{Gi}$ ) was treated daily with both nickel and ginger. The experiment was lasted for 21 days.

Results: The exposure to nickel led to a significant decrease in body weight and food intake with an increase of liver weight. Nickel treatment also produced oxidative liver injury characterized by an increase of glucose, cholesterol, triglyceride, total lipids, bilirubin, malondialdehyde (MDA) concentrations and glutamate-pyruvate transaminase, glutamic oxaloacetic transaminase, and alkaline phosphatase activities. Meanwhile, serum total proteins and liver reduced glutathione (GSH) levels, catalase, GSH peroxidase, and GSH superoxide dismutase activities were decreased. These results are substantiated with marked changes in the histopathology, whereas the supplementation of ginger resulted in a restoration of the previous parameters.

Conclusion: It seems that ginger supplementation is a potent factor for reducing the oxidative severity of nickel hepatotoxicity through its antioxidant action.

Keywords: Nickel, Ginger, Glutathione, Liver, Hepatotoxicity, Rats.

(C) 2019 The Authors. Published by Innovare Academic Sciences Pvt Ltd. This is an open access article under the CC BY license (http://creativecommons. org/licenses/by/4. 0/) DOI: http://dx.doi.org/10.22159/ajpcr.2019.v12i9.34393

\section{INTRODUCTION}

Heavy metal hazards on human and animal health are increased and represent global environmental problems [1]. There are a large group of substances commonly found in the environment as natural elements or as a result of human anthropogenic activities. Nickel (Ni) is one of those elements that may exist in various forms [2]. The metal is widespread distribution in the environment due to its wide utilization in various industries. Ni is also a nutritionally essential trace element for several animal species, microorganisms, and plants [3]. Humans are generally exposed to Ni through food, water, and air produced from wide different sources including the production of stainless steel, alloys, catalysts, foundries, welding rods, jewelry, paints, and dental and medical implantation, coinage, electroplating, and batteries manufacture $[4,5]$. Moreover, Ni cannot be metabolized and accumulates in the body, where it can be found in high level in certain organs, especially liver, kidney, and excreted through bile and urine [6]. Liver is a vital organ that has many functions including detoxification of drugs, protein synthesis, secretion of bile, storage of glycogen, and vitamins [7]. Ni is a well-known cytotoxic metal that may affect various organs, particularly liver cells [8]. The metal generates reactive oxygen species (ROS), which lead to lipid peroxidation (LPO), oxidation of DNA, and proteins and results in cell apoptosis [9], immunotoxic [10], hematotoxicity [11], neurotoxic [12], reproductive toxic [13], pulmonary toxic [14], hepatotoxicity [15], and nephrotoxicity [16]. A number of medicinal plants have been described to acquire ROS scavenging and cytoprotective properties $[17,18]$. In recent years, the natural products and their active ingredients as sources for new drug discovery have attracted attention of many scientists. Ginger, the rhizome of Zingiber officinale, is one of the most widely used species of the ginger family (Zingiberaceae). In other words, it is the most commonly used spice over the entire world. It contains more than
60 different active ingredients including volatile (hydrocarbons and sesquiterpenes) and non-volatile (gingerols, shogaols, paradols, and zingerone) compounds, in addition to various minerals, vitamins, and enzymes [19-21]. Ginger is a strong antioxidant substance and may either mitigate or prevent generation of free radicals and protect the cells from lipid oxidation [22]. Hence, ginger is known to have many health benefits and applied to treat respiratory diseases [23], nausea [24], and a cholesterol-lowering herb [25]. Furthermore, it has reported that ginger possesses other several beneficial pharmacological effects including gastroprotective [26], antiviral [27], and antidiabetic [28]. Thus, the present study was designed to evaluate whether ginger supplementation could have a protective effect against $\mathrm{Ni}$-induced hepatotoxicity in male albino Wistar rats.

\section{MATERIALS AND METHODS}

\section{Chemicals}

$\mathrm{Ni}$ sulfate $\left(\mathrm{NiSO}_{4} 6 \mathrm{H}_{2} \mathrm{O}\right), 5$, 5'dithiobis-(2-nitrobenzoic acid (DTNB) and reduced glutathione (GSH), epinephrine, and thiobarbituric acid were supplied by Sigma Chemical Co. (St. Louis, France) and all other chemicals used in the experiment were of analytical grade.

\section{Preparation of ginger}

Fresh Zingiber rhizomes was purchased from the local market, washed, peeled coarsely minced, and cut into small pieces air dried, and pulverized with a blender to fine powder and preserved in airtight containers at room temperature until the preparation of experimental diet.

\section{Animals}

Thirty-two female albino (Wistar) rats with a body weight of 216223 g were obtained from Pasteur Institute, Algiers, Algeria. Animals 
were acclimated for 2 weeks for adaptation under the same laboratory conditions of photoperiod ( $12 \mathrm{~h}$ light $/ 12 \mathrm{~h}$ dark) with a relative humidity of $40 \%$ and room temperature of $22 \pm 2{ }^{\circ} \mathrm{C}$. Food and water were provided ad libitum.

\section{Experimental design}

Animals were randomly divided into four groups of eight each. One served as a control group. The second group (Gi) received a standard diet supplemented with $20 \mathrm{~g} / \mathrm{kg}$ diet of ginger. The third group ( $\mathrm{Ni}$ ) was given $\mathrm{Ni} 800 \mathrm{mg} / \mathrm{L}$ in their drinking water as $\mathrm{Ni}$ sulfate $\left(\mathrm{NiSO}_{4} 6 \mathrm{H}_{2} \mathrm{O}\right)$ and the fourth group $(\mathrm{Ni}+\mathrm{Gi})$ was treated with both ginger and $\mathrm{Ni}$. The doses of $\mathrm{Ni}$ and ginger used in the present experiment were selected on the basis of previous studies of Sidhu et al. [29] and Krim et al. [30], respectively. The experimental procedures were carried out according to the National Institute of Health guidelines for animal care and approved by the ethics committee of our institution. Treatments of rats continued for a period of 3 weeks. Body weight and food intake were recorded regularly. At the end of the experiment, animals were sacrificed by decapitation without anesthesia to avoid animals stress. At the time of sacrifice, blood was transferred into ice-cold centrifuged tubes. Tubes were then centrifuged for $10 \mathrm{~min}$ at $3000 \mathrm{rpm}$ and serum was used for glucose, total protein, direct bilirubin, glutamic-pyruvic transaminase (GPT), glutamic oxaloacetic transaminase (GOT), and alkaline phosphatase (ALP) assays. Liver was removed immediately and one part was processed immediately for assaying LPO (MDA), reduced GSH, and antioxidant enzyme activities including GSH peroxidase (Px), catalase (CAT), and superoxide dismutase (SOD). The other parts were used for the histological study.

\section{Analytical methods}

Determination of biochemical parameters

Glucose, GPT, GOT, ALP, total proteins, and direct bilirubin were assessed using Spinreact Laboratory Spain diagnostic kits and spectrophotometer (Jenway 6505, Jenway LTD, Essex, UK). The references of kits were as follows: Glucose-41011, GOT-1001161, GPT-1001171, ALP-1001131, total proteins-1001291, and direct bilirubin-1001041.

\section{Measurement of hepatic oxidative stress parameters \\ Tissue preparation}

About $1 \mathrm{~g}$ of liver was homogenized in $2 \mathrm{ml}$ of buffer solution of phosphate-buffered saline 1:2 (w/v; $1 \mathrm{~g}$ tissue with $2 \mathrm{ml}$ TBS, $\mathrm{pH}$ 7.4). Then, the homogenates were centrifuged at $\times 10,000 \mathrm{~g}$ for $15 \mathrm{~min}$ at $4^{\circ} \mathrm{C}$ and the resultant supernatant was used for the determination of MDA, GSH, GSH-Px, CAT, SOD, and liver proteins.

\section{Estimation of LPO (MDA)}

The LPO level in liver homogenate was measured as malondialdehyde (MDA), which is the end product of LPO, and reacts with thiobarbituric acid (TBA) as a TBA reactive substance to produce a red-colored complex with a peak absorbance at $532 \mathrm{~nm}$ according to the method of Buege and Aust [31].

\section{Estimation of reduced GSH}

Liver GSH content was estimated using a colorimetric technique, as mentioned by Ellman [32] modified by Jollow et al. [33], based on the development of yellow color when DTNB is added to compounds containing sulfhydryl groups. In brief, $0.8 \mathrm{ml}$ of liver supernatant was added to $0.3 \mathrm{ml}$ of $0.25 \%$ sulfosalicylic acid. Then, tubes were centrifuged at $\times 2500 \mathrm{~g}$ for $15 \mathrm{~min}$. Supernatant $(0.5 \mathrm{ml})$ was mixed with $0.025 \mathrm{ml}$ of $0.01 \mathrm{M}$ DTNB and $1 \mathrm{ml}$ phosphate buffer $(0.1 \mathrm{M}, \mathrm{pH} 7.4)$. The absorbance at $412 \mathrm{~nm}$ was recorded. Finally, total GSH content was expressed as n mol GSH/mg protein.

\section{Determination of GSH-Px}

GSH-Px activity was measured by the procedure of Flohé and Günzler [34]. Supernatant obtained after centrifuging $5 \%$ liver homogenate at $\times 1500 \mathrm{~g}$ for $10 \mathrm{~min}$ followed by $\times 10,000 \mathrm{~g}$ for $30 \mathrm{~min}$ at $4^{\circ} \mathrm{C}$ was used for GSH-Px assay. About $1 \mathrm{ml}$ of reaction mixture was prepared which contained $0.3 \mathrm{ml}$ of phosphate buffer $(0.1 \mathrm{M}, \mathrm{pH} 7.4)$,
$0.2 \mathrm{ml}$ of GSH ( $2 \mathrm{mM}), 0.1 \mathrm{ml}$ of sodium azide $(10 \mathrm{mM}), 0.1 \mathrm{H}_{2} \mathrm{O}_{2}(1 \mathrm{mM})$, and $0.3 \mathrm{ml}$ of liver supernatant. After incubation at $37^{\circ} \mathrm{C}$ for $15 \mathrm{~min}$, the reaction was terminated by addition of $0.5 \mathrm{ml} \mathrm{5 \%} \mathrm{TCA}$. Tubes were centrifuged at $\times 1500 \mathrm{~g}$ for $5 \mathrm{~min}$ and the supernatant was collected. Subsequently, $0.2 \mathrm{ml}$ of phosphate buffer $(0.1 \mathrm{M}, \mathrm{pH} 7.4)$ and $0.7 \mathrm{ml}$ of DTNB $(0.4 \mathrm{mg} / \mathrm{ml})$ were added to $0.1 \mathrm{ml}$ of reaction supernatant. After mixing, absorbance was recorded at $420 \mathrm{~nm}$.

\section{Assay of CAT}

CAT activity was determined according to the method of Aebi [35]. The reaction mixture $(1 \mathrm{ml})$ that contained $0.78 \mathrm{ml}$ of phosphate buffer (0.1 M, pH 7.4), $0.2 \mathrm{ml}$ of liver supernatant, and $0.02 \mathrm{ml}$ of $\mathrm{H}_{2} \mathrm{O}_{2}(0.5 \mathrm{M})$ was prepared. The reaction was started by adding $\mathrm{H}_{2} \mathrm{O}_{2}$ and decomposition was monitored by following the decrease in absorbance at $240 \mathrm{~nm}$ for $1 \mathrm{~min}$. The enzyme activity was calculated using an extinction coefficient of $0.043 \mathrm{mM}^{-1} / \mathrm{cm}$.

\section{Estimation of SOD}

SOD activity was determined according to the method described by Misra and Fridonich [36]. About $10 \mu \mathrm{l}$ of tissue homogenate were added to $970 \mu \mathrm{l}$ of EDTA-sodium carbonate buffer $(0.05 \mathrm{M})$ at $\mathrm{pH} 10.2$. The reaction was started by adding $20 \mu \mathrm{l}$ of epinephrine $(30 \mathrm{mM})$ and the activity was measured at $480 \mathrm{~nm}$ for $4 \mathrm{~min}$.

\section{Protein determination}

The protein content of tissues samples was measured by the method of Bradford [37] using bovine serum albumin as a standard.

\section{Histological study}

The histological examination of livers was carried out as follows: Liver was dissected and immediately fixed in Bouin solution for $24 \mathrm{~h}$, processed using a graded ethanol series and then embedded in paraffin. The paraffin sections were cut into $5 \mu \mathrm{m}$ thick slices and stained with hematoxylin and eosin. The preparations were then observed under an optical microscope and photographed [38].

\section{Statistical analysis}

Data are given as mean \pm SEM. Statistical significance of the results obtained for various comparisons was estimated by applying oneway analysis of variance followed by Student's t-test and the level of significance was set at $\mathrm{p}<0.05$.

\section{RESULTS}

Effect of treatment on body weight, liver weight, and food intake The findings illustrated in Table 1 showed that body weight and food intake of animals exposed to Ni were significantly decreased by $-36 \%$ and $-35 \%$,

Table 1: Initial body weight, final body weight, food intake, and absolute and relative liver weights of control rats treated with ginger (Gi), nickel, and nickel plus ginger ( $\mathrm{Ni}+\mathrm{Gi}$ ) after 3 weeks of treatment

\begin{tabular}{lllll}
\hline Parameter & \multicolumn{3}{l}{ Experimental groups } \\
\cline { 2 - 5 } & Control & $\mathbf{G i}$ & $\mathbf{N i}$ & $\mathbf{N i}+\mathbf{G i}$ \\
\hline $\begin{array}{l}\text { Initial body } \\
\text { weight (g) }\end{array}$ & $217 \pm 16$ & $223 \pm 15$ & $216 \pm 23$ & $216 \pm 13$ \\
$\begin{array}{l}\text { Final body } \\
\text { weight (g) }\end{array}$ & $302 \pm 17$ & $291 \pm 10$ & $191 \pm 17^{* * *}$ & $262 \pm 13^{* \# \#}$ \\
$\begin{array}{l}\text { Foodintake } \\
\text { (g/day/rat) }\end{array}$ & $20 \pm 0.56$ & $20 \pm 0.49$ & $13 \pm 1.35^{* * *}$ & $17 \pm 0.90^{* * \#}$ \\
$\begin{array}{l}\text { Absolute liver } \\
\text { weight (g) }\end{array}$ & $6.11 \pm 0.23$ & $6.16 \pm 0.32$ & $9.64 \pm 0.73^{* * *}$ & $6.72 \pm 0.36^{\# \#}$ \\
$\begin{array}{l}\text { Relative liver } \\
\text { weight (g) }\end{array}$ & $2.70 \pm 0.05$ & $2.82 \pm 0.10$ & $3.66 \pm 0.11^{* * *}$ & $2.94 \pm 0.16^{\# \#}$ \\
\hline
\end{tabular}

Values are given as mean \pm SEM, eight female rats each group. Statistically significant different from control group: ${ }^{*} \mathrm{p}<0.05,{ }^{* *} \mathrm{p}<0.01,{ }^{* * *} \mathrm{p}<0.001$; from nickel group: $\# \mathrm{p}<0.05, \# \mathrm{p}<0.01$ 
Table 2: Changes of biochemical parameters for control rats treated with ginger (Gi), nickel, and nickel plus ginger (Ni+Gi) after 3 weeks of treatment

\begin{tabular}{llll}
\hline Parameter & Experimental groups & & \\
\cline { 2 - 4 } & Control & $\mathbf{G i}$ & $\mathbf{N i}$ \\
\hline Glucose (g/l) & $1.13 \pm 0.06$ & $1.02 \pm 0.03$ & $1.35 \pm 0.07^{*}$ \\
Triglyceride (mg/dl) & $70.23 \pm 12.03$ & $64.21 \pm 2.69$ & $101.31 \pm 1.12^{* *}$ \\
Cholesterol (mg/dl) & $74.16 \pm 6.16$ & $64.83 \pm 4.95$ & $110 \pm 3.18^{* * *}$ \\
Direct bilirubin (mg/dl) & $0.40 \pm 0.18$ & $0.40 \pm 0.12$ & $0.80 \pm 0.04^{*}$ \\
Total lipids (mg/dl) & $330 \pm 8.39$ & $328.16 \pm 17.45$ & $415 \pm 18.00^{* * *}$ \\
Total protein (mg/dl) & $7.33 \pm 0.44$ & $7.69 \pm 0.35$ & $5.49 \pm 0.2^{* *}$ \\
GOT (U/L) & $75.05 \pm 1.74$ & $73.95 \pm 1.83$ & $137.72 \pm 9.91^{* * *}$ \\
GPT (U/L) & $44.33 \pm 5.67$ & $45.10 \pm 2.60$ & $6.55 \pm 0.32 \pm 6.88^{* *}$ \\
PAL (U/L) & $115 \pm 1.57$ & $115.5 \pm 0.42$ & $370 \pm 11.39^{* * * \#}$ \\
\hline
\end{tabular}

Values are given as mean \pm SEM, eight female rats each group. Statistically significant different from control group: ${ }^{*} p<0.05,{ }^{* *} \mathrm{p}<0.01,{ }^{* * *} \mathrm{p}<0.001$; from nickel group: \#p $<0.05, \# \#$ p $<0.001$, GPT: Glutamic-pyruvic transaminase, GOT: Glutamic oxaloacetic transaminase

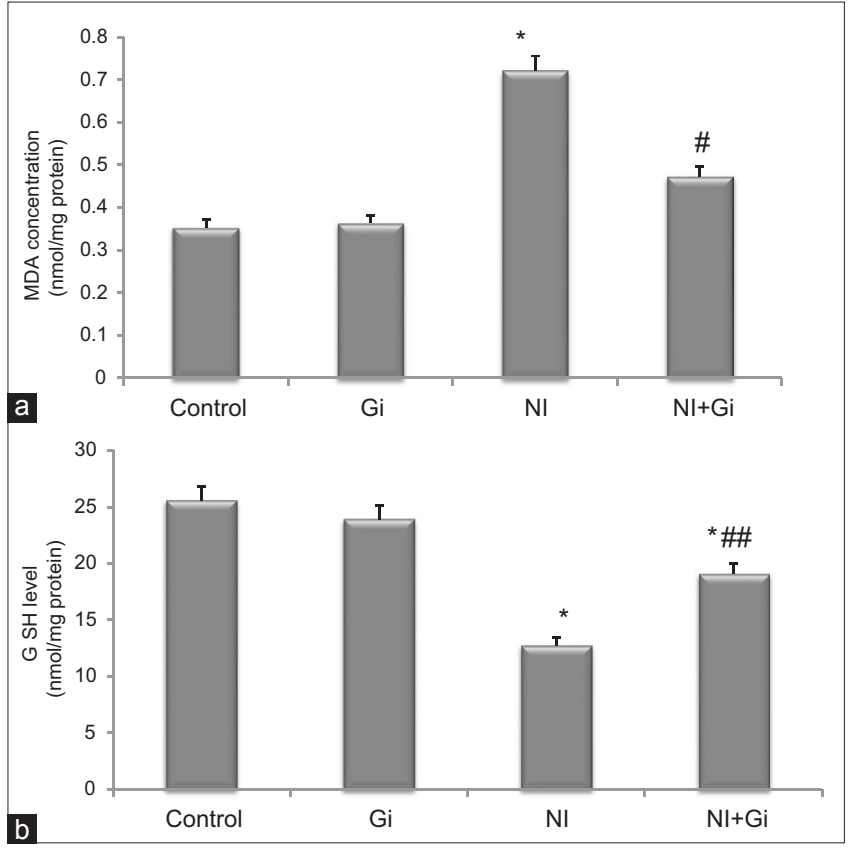

Fig. 1: ( $a$ and $b$ ) Liver MDA and glutathione concentrations of control rats treated with ginger (Gi), nickel (Ni), and Ni plus ginger ( $\mathrm{Ni}+\mathrm{Gi}$ ) after 3 weeks of treatment. Values are given as mean \pm SEM, eight female rats each group. Statistically significantly differences from control group: ${ }^{*} p<0.05$; from Ni group: ${ }^{\#} \mathbf{p}<0.05$, $\# \mathbf{p}<\mathbf{0 . 0 1}$

respectively, as compared to controls. Meanwhile, a significant increase of Ni-treated group in absolute and relative liver weights was noticed $57 \%$ and $35 \%$, respectively. However, the previous parameters were obviously restored near controls values after ginger supplementation.

\section{Effect of treatment on liver damage parameters}

Treatment with $\mathrm{Ni}$ caused a significant increase $(\mathrm{p}<0.05)$ of serum glucose and direct bilirubin; highly significant $(\mathrm{p}<0.01)$ for triglycerides, GPT, and ALP; and very high significant $(\mathrm{p}<0.001)$ for cholesterol and total lipids. Meanwhile, the concentration of serum total protein was diminished $(\mathrm{p}<0.01)$. Nevertheless, the supplementation of ginger in combination with $\mathrm{Ni}$ produced a significant recovery in the abovementioned biochemical parameters $(\mathrm{p}<0.05)$ for total protein, total lipids, triglycerides, and direct bilirubin; $\mathrm{p}<0.01$ for GPT; and $\mathrm{p}<0.001$ for glucose, cholesterol, GOT, and ALP (Table 2).

\section{Effect of treatment on hepatic oxidative stress parameters}

As shown in Figs. 1 and 2, the exposure to Ni produced a significant adverse effect on the liver redox status, which is indicated by an increase $(\mathrm{p}<0.05)$ of MDA level and a decrease of GSH $(\mathrm{p}<0.05)$ content, GSH-Px $(\mathrm{p}<0.01)$, CAT $(\mathrm{p}<0.001)$, and SOD $(\mathrm{p}<0.01)$ activities. However, supplementation with ginger in association with $\mathrm{Ni}$ ameliorated most these stress oxidative biomarkers.

\section{Histological results}

Livers section of control group (Fig. 3a) and ginger group (Fig. 3b) was showing normal hepatic plates radiating from a thin-walled central vein separated by blood sinusoids lined by endothelial cells. In contrast, liver of nickel treated group had shown pathological alterations such as the presence of cellular debris within a central vein and cytological vacuolization, inflammation and necrosis (Fig. 3c). However, the supplementation of ginger mentioned prominent recovery in the form of the hepatic histoarchitecture such as the decreased cytoplasmic vacuolization and the normal sinusoidal spaces (Fig. 3d).

\section{DISCUSSION}

It is known that liver is the most target organ of toxicity $[39,40]$. A number of drugs, chemicals, and heavy metals have been shown to alter its structure and function. Animal experiments and human studies are conclusive about metabolic adverse effects and hepatotoxicity of $\mathrm{Ni}$ element [41]. Ginger is very strong antioxidant compound, which is well documented for the attenuation of oxidant mediated liver damage induced by various xenobiotics. Therefore, this study was devoted to determine the beneficial effects of this spice on $\mathrm{Ni}$-induced oxidative liver injury in rats.

The findings of the present study showed a significant reduction in body weight of Ni exposed group. The decreased body weight is concomitant with previously reports $[42,43]$. This reduction in weights might as a result of the overall increased degeneration of lipids and proteins [9] and a decrease of appetite. The altered body weight was retrieved to near normal value due to the antioxidant effect of ginger. Many studies have reported that ginger showed a significant protective effect against damage induced by heavy metals such as arsenic and cadmium $[44,45]$. The results indicated also an augmentation of blood glucose in $\mathrm{Ni}$ animals. This may be linked with inhibition of insulin secretion from Langerhans' islets and a block of glucose utilization by cells [46], or the high glycogen breakdown and new supply of glucose production from other non-carbohydrate sources such as proteins [47]. Meanwhile, there was an amelioration of blood glucose concentration in Ni animals treated with ginger. The effect of ginger on glucose reduction could be explained by the fact that gingerol; the most important bioactive compound of ginger has a variety of mechanisms to upregulate blood glucose, it decreases hepatic glucose production and increases glucose transporter translocation from intracellular compartments to the cells surface which results in increased glucose uptake into cells [48,49]. In addition, it is reported that ginger inhibits $\alpha$-amylase and $\alpha$-glucosidase enzymes in carbohydrate digestion [50]. In the present investigation, higher activities of serum transaminases and ALP have been found in Ni-treated animals. That is an indicative of cellular leakage and 


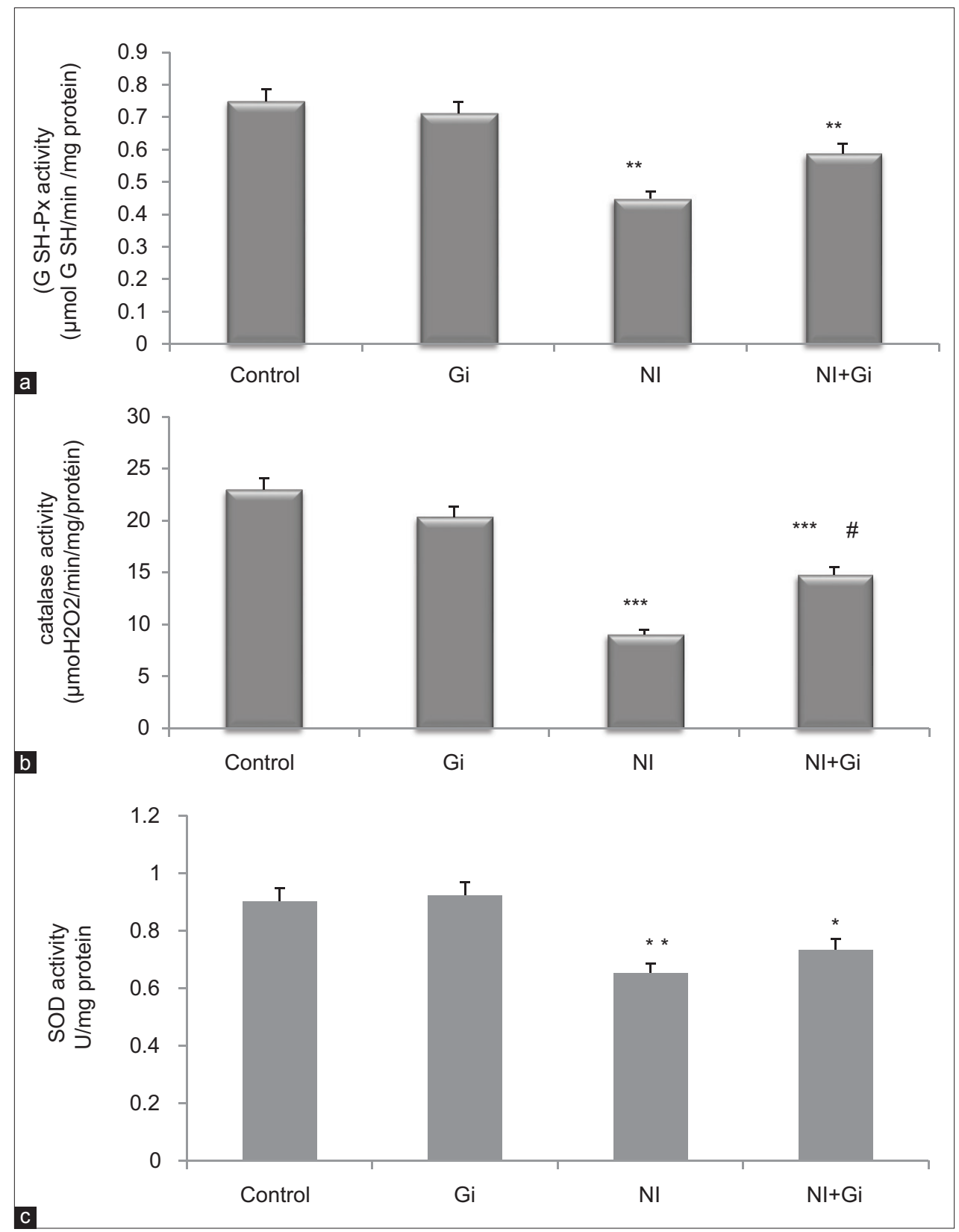

Fig. 2: (a-c) Liver glutathione-peroxidase, catalase, and superoxide dismutase activities of control rats treated with ginger (Gi), nickel (Ni), and $\mathrm{Ni}$ plus ginger $(\mathrm{Ni}+\mathrm{Gi})$ after 3 weeks of treatment. Values are given as mean \pm standard error of the mean, eight female rats each group. Statistically significant different from control group: ${ }^{*} \mathrm{p}<0.05,{ }^{* *} \mathrm{p}<0.01,{ }^{* * *} \mathrm{p}<0.001$; from Ni group: ${ }^{*} \mathrm{p}<0.05$

loss of functional integrity of the hepatic cell membranes implying hepatocellular destruction, which gives a sign on the hepatotoxic effect of this metal by the induction of oxidative stress [51]. In general, serum total protein and bilirubin concentrations signify the state of the liver damage [52]. In that case, the reduction in the proteins concentration of Ni-treated rats probably due to changes in protein synthesis and/or metabolism [53]. In addition, the discovered hyperbilirubinemia might be due to excessive heme destruction and blockage of biliary tract in Ni-treated rats. This obstruction may have resulted to mass inhibition of conjugation effect and release of unconjugated bilirubin from broken and dead hepatocytes [52]. Interestingly, the biochemical perturbations seem to be correlated with the liver histological alterations such as the presence of cellular debris within a central vein and a cytoplasmic vacuolization, plasma membrane destruction, and cellular hypertrophy. Significant restoration of hepatic serum marker enzymes, total proteins, and bilirubin was noticed in the animals treated with ginger offering protection against $\mathrm{Ni}$ toxicity in rats. This means that ginger will reduce liver damage by maintaining the integrity of the cell membrane. Otherwise, the hepatoprotective activity of ginger may be due to its direct radical scavenging activity [54]. Nickel is well known to induce oxidative damage in liver by enhancing LPO [55]. LPO is supposed to cause the destruction and damage cells membranes, leads to changes in membrane permeability and fluidity [56]. Corroborate with these findings, treatment with Ni resulted in a significant increase in LPO as indicated by the significant increase in MDA. It has been reported that administration of Ni resulted in the accumulation of iron, which, in turn, generates ROS through Haber-Weiss and Fenton's reaction [4]. The significant decrease in GSH in Ni-treated group was in accordance with the previous reports $[41,57]$. The findings showed also that $\mathrm{Ni}$ administration induced a significant decrease GSH-Px, CAT, and SOD activities, which confirm the work of Boulila et al. [58], Hfaïedh et al. [59], and Misra et al. [55]. This might be due to their increased utilization in scavenging free radicals induced by the metal, thus causing irreversible inhibition in their activities or due to direct binding of the metal to the 


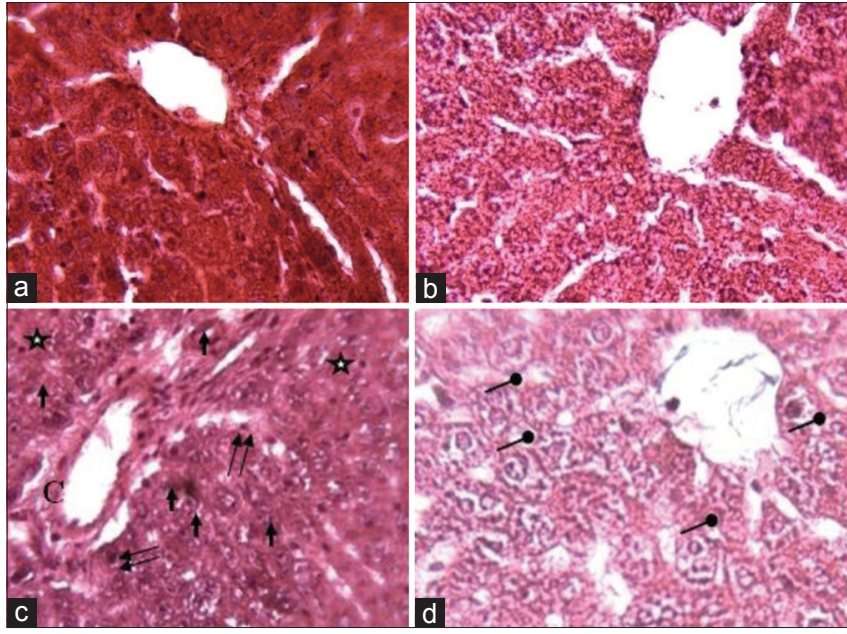

Fig. 3: Light photomicrograph of liver sectional histology from control rats (a), ginger (b), nickel (Ni) (c) and $\mathrm{Ni}+$ ginger (d) $(H$ and $E, \times 400) . \uparrow \uparrow$ : Indicate a presence of cellular degeneration, necroses hepatocytaire. $\nleftarrow$ : Multifocal inflammatory of hepatocytes. $\boldsymbol{f}$ : Hepatocyte vacuolization. $\boldsymbol{\rho}$ : Regenerative cells

active sites of these enzymes [60]. In that case, SOD was inhibited by hydrogen peroxide, while GSH-Px and CAT were inhibited by an excess of superoxide radical [61]. After supplementation of ginger with $\mathrm{Ni}$, the activity of most assayed enzymes, GSH and MDA, was normalized near the values of the control group, indicating the ability of this spice to restore these stress oxidative biomarkers. Several studies have shown that consumption of nutrient-rich antioxidants such as ginger decreased heavy metals toxicity and diabetic complications [62,63]. In brief, ginger has an ability to increase the intracellular activities of SOD, CAT, and GSH enzymes and has synergistically combats oxidative stress by scavenging free radicals and augmenting endogenous antioxidant activities [64]. This may be due to ginger contain many antioxidants compounds that may modulate the antioxidants enzymes in $\mathrm{Ni}$ hepatotoxicity. Gingerol is one among these antioxidant compounds which are responsible for the inhibition of LPO.

\section{CONCLUSION}

The investigation demonstrated that $\mathrm{Ni}$ is capable of causing marked oxidative stress in addition to deplete the antioxidants and inhibiting antioxidant enzyme activities. However, the treatment with ginger attenuated the Ni-induced oxidative hepatotoxicity through its antioxidant properties. Hence, the study indicated that ginger could be regarded as a potential candidate for the therapeutic intervention in hepatotoxicity.

\section{ACKNOWLEDGMENT}

Authors thank members of Pasteur Institute, Algiers for providing rats and the ministry of higher education, Algeria for the financial support.

\section{AUTHORS' CONTRIBUTIONS}

Zine Kechrid formulated the present hypothesis. Zine Kechrid was also responsible for writing the report. Sara Derbal was responsible for the analysis of the data.

\section{CONFLICTS OF INTEREST}

The authors declare that they have no conflicts of interest.

\section{REFERENCES}

1. Maity S, Roy S, Chaudhury S, Bhattacharya S. Antioxidant responses of the earthworm Lampito mauritii exposed to $\mathrm{Pb}$ and $\mathrm{Zn}$ contaminated soil. Environ Pollut 2008;151:1-7.

2. Sengupta P. Environmental and occupational exposure of metals and their role in male reproductive functions. Drug Chem Toxicol
2013;36:353-68

3. Cempel M, Nikel G. Nickel: A review of its sources and environmental toxicology. Pol J Environ Stud 2006;15:375-82.

4. Environmental Protection Agency United States. Health Assessment Document for Nickel. National Service Center for Environmental Assessment, Office of Research and Development. Washington DC: Environmental Protection Agency United States; 1985.

5. Buekers J, De Brouwere K, Lefebvre W, Willems H, Vandenbroele M, Van Sprang P, et al. Assessment of human exposure to environmental sources of nickel in Europe: Inhalation exposure. Sci Total Environ 2015;521-522:359-71.

6. Onkelinx C, Becker J, Sunderman FW Jr. Compartmental analysis of the metabolism of $63 \mathrm{Ni}(\mathrm{II})$ in rats and rabbits. Res Commun Chem Pathol Pharmacol 1973;6:663-76.

7. El-Bakry HA, El-Sherif G, Rostom RM. Therapeutic dose of green tea extract provokes liver damage and exacerbates paracetamol-induced hepatotoxicity in rats through oxidative stress and caspase 3-dependent apoptosis. Biomed Pharmacother 2017;96:798-811.

8. Adjroud O. The toxic effects of nickel chloride on liver, erythropoiesis, and development in wistar albino preimplanted rats can be reversed with selenium pretreatment. Environ Toxicol 2013;28:290-8.

9. Wang Y, Wang SY, Jia L, Zhang L, Ba JC, Han D, et al. Nickel-refining fumes induced DNA damage and apoptosis of NIH/3T3 cells via oxidative stress. Int J Environ Res Public Health 2016;13:629.

10. Vijayavel K, Gopalakrishnan S, Thiagarajan R, Thilagam H. Immunotoxic effects of nickel in the mud crab Scylla serrata. Fish Shellfish Immunol 2009;26:133-9.

11. Laylani LA. Effect of Carthamus tinctorius safflower aqueous extract against nickel chloride induces hematotoxicity and immunotoxicity in adult male rabbits. Ibn Al Haitham J Pure Appl Sci 2017;30:19-26.

12. Song X, Kenston SS, Kong L, Zhao J. Molecular mechanisms of nickel induced neurotoxicity and chemoprevention. Toxicology 2017;392:47-54.

13. Sun $\mathrm{H}, \mathrm{Wu}$ W, Guo J, Xiao R, Jiang F, Zheng L, et al. Effects of nickel exposure on testicular function, oxidative stress, and male reproductive dysfunction in Spodoptera litura Fabricius. Chemosphere 2016;148:178-87.

14. Phillips JI, Green FY, Davies JC, Murray J. Pulmonary and systemic toxicity following exposure to nickel nanoparticles. Am J Ind Med 2010;53:763-7

15. Bouhalit S, Kechrid Z. Protective role of L-cysteine against nickel induced hepatotoxicity in Albino Wistar rats. J Pharmacol Med Chem 2018;2:32-5

16. Bouhalit S, Kechrid Z, EL-Feki A. Effect of silymarin extracted from Silybum marlanum on nickel hematotoxicity and nephrotoxicity in male albino Wistar rats. Int J Pharm Pharm Sci 2017;9:84-9.

17. Elangovan P, Amudha K, Shagirtha K. Naringin improves nickelinduced alterations of acetylcholinesterase, adenosine triphosphatases, and oxidative stress in brain of rats. J Nat Prod Biom Res 2015:1:21-8.

18. Anilakumar KR, Saritha V, Khanum F, Bawa AS. Ameliorative effect of ajwain extract on hexachlorocyclohexane-induced lipid peroxidation in rat liver. Food Chem Toxicol 2009;47:279-82.

19. Ahmad B, Rehman MU, Amin I, Arif A, Rasool S, Bhat SA, et al. A review on pharmacological properties of zingerone (4-(4-hydroxy-3-methoxyphenyl)-2-butanone). ScientificWorldJournal 2015;2015:816364.

20. Tao Y, Li W, Liang W, Van Breemen RB. Identification and quantification of gingerols and related compounds in ginger dietary supplements using high-performance liquid chromatography-tandem mass spectrometry. J Agric Food Chem 2009;57:10014-21.

21. Ali BH, Blunden G, Tanira MO, Nemmar A. Some phytochemical, pharmacological and toxicological properties of ginger (Zingiber officinale roscoe): A review of recent research. Food Chem Toxicol 2008;46:409-20

22. Jeena K, Liju VB, Kuttan R. Antioxidant, anti-inflammatory and antinociceptive activities of essential oil from ginger. Indian J Physiol Pharmacol 2013;57:51-62

23. Khan AM, Shahzad M, Asim MB, Imran M, Shabbir A. Zingiber officinale ameliorates allergic asthma via suppression of th2-mediated immune response. Pharm Biol 2015;53:359-67.

24. Lete I, Allué J. The effectiveness of ginger in the prevention of nausea and vomiting during pregnancy and chemotherapy. Integr Med Insights 2016;11:11-7.

25. Murad S, Niaz K, Aslam H. Effects of ginger on LDL-C, total cholesterol and body weight. Clin Med Biochem 2018;4:1-3.

26. Nanjundaiah SM, Annaiah HN, Dharmesh SM. Gastroprotective effect of ginger rhizome (Zingiber officinale) extract: Role of gallic 
acid and cinnamic acid in $\mathrm{H}(+), \mathrm{K}(+)$-ATPase/H. pylori inhibition and anti-oxidative mechanism. Evid Based Complement Alternat Med 2011;2011:249487.

27. Chang JS, Wang KC, Yeh CF, Shieh DE, Chiang LC. Fresh ginger (Zingiber officinale) has anti-viral activity against human respiratory syncytial virus in human respiratory tract cell lines. J Ethnopharmacol 2013;145:146-51.

28. Al-Amin ZM, Thomson M, Al-Qattan KK, Peltonen-Shalaby R, Ali M. Anti-diabetic and hypolipidaemic properties of ginger (Zingiber officinale) in streptozotocin-induced diabetic rats. Br J Nutr 2006;96:660-6

29. Sidhu P, Garg ML, Dhawan DK. Protective role of zinc in nickel induced hepatotoxicity in rats. Chem Biol Interact 2004;150:199-209.

30. Krim M, Messaadia A, Maidi I, Aouacheri O, Saka S. Protective effect of ginger against toxicity induced by chromate in rats. Ann Biol Clin (Paris) 2013;71:165-73.

31. Buege JA, Aust SD. Microsomal lipid peroxidation. Methods Enzymol 1984;105:302-10.

32. Ellman GL. Tissue sulfhydryl groups. Arch Biochem Biophys 1959;82:70-7.

33. Jollow DJ, Mitchell JR, Zampaglione N, Gillette JR. Bromobenzeneinduced liver necrosis. Protective role of glutathione and evidence for 3,4-bromobenzene oxide as the hepatotoxic metabolite. Pharmacology 1974;11:151-69.

34. Flohé L, Günzler WA. Assays of glutathione peroxidase. Methods Enzymol 1984;105:114-21.

35. Aebi H. Catalase in vitro. Methods Enzymol 1984;105:121-6.

36. Misra HP, Fridovich I. Superoxide dismutase: "Positive" spectrophotometric assays. Anal Biochem 1977;79:553-60.

37. Bradford MM. A rapid and sensitive method for the quantitation of microgram quantities of protein utilizing the principle of protein-dye binding. Anal Biochem 1976;72:248-54.

38. Hould R. Techniques d'histopathologie et de Cytopathologie. Paris: Editions Maloine; 1984.

39. Layachi N, Kechrid Z. Combined protective effect of Vitamins C and $\mathrm{E}$ on cadmium induced oxidative liver injury in rats. Afr $\mathrm{J}$ Biot 2012;11:16013-20.

40. Gueroui M, Kechrid Z. Evaluation of some biochemical parameters and brain oxidative stress in experimental rats exposed chronically to silver nitrate and the protective role of vitamin E and selenium. Toxicol Res 2016;32:301-9.

41. Djemli S, Kechrid Z. Preventive effect of zinc on nickel-induced oxidative liver injury in rats. Afr J Biot 2013;12:7112-19.

42. Dahdouh F, Attalah S, Djabar MR, Kechrid Z. Effect of the joint supplementation of Vitamin C and Vitamin E on nickel heamatotoxicity and nephrotoxicity in male Swiss albino mice. Int J Pharm Pharm Sci 2016;8:234-9.

43. Hamdiken M, Kechrid Z. Chard (Beta vulgaris Var. Cilca) extract modulates status, glucose level and antioxidant values in diabetic rats fed zinc deficiency diet. Int J Pharm Pharm Sci 2017;9:297-304.

44. Egwurugwu JN, Ufearo CS, Abanobi OC, Nwokocha CR, Duruibe JO, Adeleye GS, et al. Effects of ginger (Zingiber officinale) on cadmium toxicity. Afr J Biot 2007;6:2078-82.

45. Sharma S, Singhgill A. Restorative effects of Zingber officinale on arsenic-induced genottoxic effects in chromosomal structure of mice. Asian J Pharm Clin Res 2018;11:471-5.

46. Dormer RL, Kerbey AL, McPherson M, Manley S, Ashcroft SJ, Schofield JG, et al. The effect of nickel on secretory systems. Studies on the release of amylase, insulin and growth hormone. Biochem $\mathrm{J}$ 1974; 140:135-42.

47. Cartañà J, Arola L. Nickel-induced hyperglycaemia: The role of insulin and glucagon. Toxicology 1992;71:181-92.

48. Akash MS, Rehman K, Tariq M, Chen S. Zingiber officinale and Type 2 diabetes mellitus: Evidence from experimental studies. Crit Rev Eukaryot Gene Expr 2015;25:91-112.

49. Li Y, Tran VH, Duke CC, Roufogalis BD. Gingerols of Zingiber officinale enhance glucose uptake by increasing cell surface GLUT4 in cultured L6 myotubes. Planta Med 2012;78:1549-55.

50. Rani MP, Padmakumari KP, Sankarikutty B, Cherian OL, Nisha VM, Raghu KG, et al. Inhibitory potential of ginger extracts against enzymes linked to Type 2 diabetes, inflammation and induced oxidative stress. Int J Food Sci Nutr 2011;62:106-10.

51. Tikare SN, Yendigeri S, Das Gupta A, Dhundasi SA, Das KK. Protective effect of $\alpha$-tocopherol against hematotoxicity, hepatotoxicity and nephrotoxicity induced by nickel sulfate in male albino rats. Indian J Physiol Pharmacol 2013;57:280-92.

52. Sabiu S, Sunmonu TO, Ajani EO, Ajiboye TO. Combined administration of silymarin and Viamin C stalls acetaminophen-mediated hepatic oxidative insults in Wistar rats. Rev Bras Farmacogn 2015;25:9-34.

53. Chinoy NJ, Memon MR. Beneficial effects of some vitamins and calcium on fluoride and aluminium toxicity on gastrocnemius muscle and liver of male mice. Fluoride 2001;34:21-33.

54. Ajith TA, Nivitha V, Usha S. Zingiber officinale roscoe alone and in combination with alpha-tocopherol protect the kidney against cisplatininduced acute renal failure. Food Chem Toxicol 2007;45:921-7.

55. Misra M, Rodriguez RE, Kasprzak KS. Nickel induced lipid peroxidation in the rat: Correlation with nickel effect on antioxidant defense systems. Toxicology 1990;64:1-7.

56. Rems L, Viano M, Kasimova MA, Miklavčič D, Tarek M. The contribution of lipid peroxidation to membrane permeability in electropermeabilization: A molecular dynamics study. Bioelectrochemistry 2019;125:46-57.

57. Chen CY, Wang YF, Lin YH, Yen SF. Nickel-induced oxidative stress and effect of antioxidants in human lymphocytes. Arch Toxicol 2003;77:123-30.

58. Boulila S, Elfeki A, Oudadesse H, Elfeki H. Substitution effects of a carbonated hydroxyapatite biomaterial against intoxication chloride nickel-exposed rats. Toxicol Mech Methods 2015;25:155-65.

59. Hfaiedh N, Allagui MS, Hfaiedh M, Feki AE, Zourgui L, Croute F, et al. Protective effect of cactus (Opuntiac ficus indica) cladode extract upon nickel-induced toxicity in rats. Food Chem Toxicol 2008;46:3759-63.

60. Ihechiluru NB, Henry AN, Taiwo IE. Heavy metal bioaccumulation and oxidative stress in austroaeschnainermis (dragon fly) of the Lagos urban ecosystem. J Environ Chem Ecotoxicol 2015;7:11-19.

61. Reham ZH, Mohammad SA. Amelioration of paracetamol hepatotoxicity and oxidative stress on mice liver with silymarin and extract supplements. Asian Pac J Trop Biomed 2015;5:521-31.

62. Reddy YA, Chalamaiah M, Ramesh B, Balaji G, Indira P. Ameliorating activity of ginger (Zingiber officinale) extract against lead induced renal toxicity in male rats. J Food Sci Technol 2014;51:908-14.

63. Khattab HA, Al-Amoudi NS, Al-Faleh, AA. Effect of ginger, curcumin and their mixture on blood glucose and lipids in diabetic Rats. Life Sci J 2013;10:428-42.

64. Shobana S, Naidu KA. Antioxidant activity of selected Indian spices. Prostaglandins Leukot Essent Fatty Acids 2000;62:107-10. 